Рекомендована д. фрармац. наук, профр. О. М. Заліською

УДК 615.1:616.72:339.13

\title{
АНАЛІЗ ПРОБЛЕМ ТА РОЗРОБКА ЗАХОДІВ ЩОДО ПІДВИЩЕННЯ ЕФЕКТИВНОСТІ ФАРМАЦЕВТИЧНОГО ЗАБЕЗПЕЧЕННЯ ХВОРИХ НА ЛЕЙКОЗИ В УKPAÏHI
}

\author{
СГ. Л. Панфілова, О. В. Цурікова \\ Національний фрармацевтичний університет, Харків
}

Резюме: у статті представлено результати анкетування лікарів онкологів та гематологів за комплексом питань, що стосуються організації надання медичної допомоги та фрармацевтичного забезпечення хворих на лейкози в Україні. За одностайною оцінкою лікарів вирішення проблем в організації ефективної медичної та фрармацевтичної допомоги повинно реалізовуватися у площині впровадження обов'язкового медичного страхування у практичну охорону здоров'я. Майже кожен другий експерт зазначив про низький рівень задоволення потреби у лікарських препаратах (варіант відповіді «менш ніж 25\% від потреби у ліках»), а більше половини опитаних вважає недоцільним віддавати перевагу вітчизняним препаратам-аналогам при бюджетних закупівлях ліків. До основних проблем в організації фрармацевтичного забезпечення хворих на лейкози експертами віднесені фрінансові за змістом («низькі доходи населення» та «недостатній рівень бюджетного фрінансування цільової програми «Онкологія»), важливого значення набуває також «відсутність системної та чіткої державної політики у фрармацевтичному секторі економіки». За результатами проведених досліджень розроблений перелік заходів щодо підвищення есрективності фрармацевтичного забезпечення хворих на лейкози в Україні, які повинні реалізовуватися на двох рівнях (макроекономічному та рівні закладів охорони здоров'я).

Ключові слова: експертне опитування, лейкоз, фрармацевтична допомога, фрармацевтичне забезпечення.

Вступ. За даними Національного канцер-реєстру, лейкози стабільно займають перші позиції в структурі захворюваності та смертності населення від злоякісних новоутворень серед вікової групи від 0 до 17 років, яка фрормує потенціал нашої держави та суспільства в цілому. За умов негативної тенденції до планомірного вимирання населення України, яка спостерігається упродовж останнього десятиліття, високий рівень смертності від лейкозів серед найбільш перспективної групи мешканців країни виглядає як соціально значуще питання. За умов фрінансовоекономічної кризи i, як наслідок, хронічного десріциту у фрінансуванні вітчизняної онкогематологічної служби, доступність фрармацевтичної допомоги, що надається хворим на лейкози в Україні, залишається вкрай низькою [2, 5-7]. Важливе місце у визначенні напрямків подолання проблеми низького рівня ефективності надання медичної та фрармацевтичної допомоги хворим на лейкози має аналіз думки лікарів (онкологів, гематологів), які в системі охорони здоров'я (CO3) постають як основний взаємопов'язувальний елемент у відносинах між пацієнтами та фрармацевтичними працівниками $[1,4,7]$.

Методи дослідження полягали у визначенні проблем та розробці заходів щодо підвищення ефрективності організації фрармацевтичного забезпечення хворих на лейкози в Україні. Для досягнення мети були розроблені такі завдання: провести анкетування лікарів та обробити його результати; визначити основні проблеми в організації надання медичної та фрар- мацевтичної допомоги хворим на лейкоз в Україні за комплексом напрямків; за результатами систематизації результатів попередньо проведених досліджень та даних анкетування лікарів розробити заходи 3 підвищення рівня ефективності фрармацевтичного забезпечення хворих на лейкози в Україні.

Об'єктами досліджень були обрані дані експертного опитування лікарів онкологів та гематологів, яке проводилось протягом 2012-2014 рр. у Донецькій, Дніпропетровській, Львівській, Вінницькій, Полтавській, Харківській, Київській областях та АР Крим (м. Сімферополь, м. Керч, м. Євпаторія, м. Севастополь). При визначенні обсягу вибірки респондентів враховано рівень необхідної точності отриманих досліджень. Так, точність повинна була бути такою, що допустимий інтервал встановлювався на рівні $\Delta= \pm 0,05$, а 95,0 \% - необхідний рівень достовірності [8]. Всього було розіслано 150 (100\%) анкет, з яких було повернено 137 (91,33 \%) примірників. Внаслідок недбалого ставлення до роботи було прийнято 126 (84,0 \%) анкет. 3 кожної анкети розраховували показник компетентності респондентів [7]. У подальшому використовували дані анкет експертів з дуже високим, високим та достатнім рівнями компетентності (92 опитаних - 73,02 \% від загальної кількості прийнятих до роботи анкет). 3 метою отримання достовірних даних за допомогою табличного процесоpa Microsoft Office Excel 2010 та стандартних програм прикладного статистичного аналізу Statistica 6.0 (ліцензія програмного продукту V.7. English - V.6 Russia

ISSN 2312-0967. Pharmaceutical review. 2015. № 2 
К 892818) була здійснена оцінка однорідності сукупності опитаних та ступінь узгодженості їх думок [8].

Результати й обговорення. Результати обробки даних на перше запитання анкети («Вкажіть, будь-ласка, основні фрактори, які впливають на призначення ЛП, що використовуються у патогенетичному лікуванні лейкозів») наведені у таблиці 1. Нами був складений рейтинг важливості фракторів у призначенні ЛП, які використовуються у фрармакотерапії лейкозів.

Як видно даних таблиці 1, лідируючими є фактори клініко-економічного та нормативного-правового характеру. Замикають рейтинг фактори, що пов'язані з традиційністю призначень та можливістю застосування того або іншого найменування ЛП за відсутністю більш ефективного. Такі важливі для організації ефективного фрармацевтичного забезпечення фрактори, як «низька ціна препарату» та «інфрормація про наявність ЛП в аптечній мережі, що обслуговує 3О3», посіли у рейтингу VI та VII позиції. На закрите запитання «Чи задоволені Ви рівнем організації та фрінансуванням профілактичної роботи, лікувально-діагностичного процесу та фрармацевтичного забезпечення хворих на лейкози в Україні?» 3 загальної кількості опитаних тільки 8 (8,70 \%) експертів дали стверджувальну відповідь, 6 опитаних (6,52 \%) мали труднощі 3 відповіддю. Більшість експертів (63 експерти або 68,48 \%) дали варіант відповіді «Частково задоволені», а 15 опитаних (16,30 \%) відмітили негативний варіант відповіді. Тобто кожен шостий опитаний лікар висловив своє незадоволення загальним рівнем організації та орі- нансуванням медичної допомоги та фрармацевтичним забезпеченням хворих на лейкози в Україні.

Далі лікарі повинні були визначити основні напрямки вирішення зазначеної проблеми. Результати досліджень представлені у таблиці 2. Слід зазначити, що до переліку варіантів відповідей спеціально були включені різні за рівнем реалізації (макро- та мікрорівень) та характером напрямки. На нашу думку, це дозволяє розширити масштаб розгляду проблеми. До трійки напрямків-лідерів, за оцінкою фрахівців, увійшли наступні: «реформування вітчизняної системи охорони здоров'я у напрямку впровадження моделі OMC; «матеріально-технічне переобладнання 303»; «активізація та координація діяльності громадських та благодійних фрондів». Наявність останнього з поданих напрямків у складі трійки-лідерів $є$ специсрічним для онкогематології. Активна підтримка хворих на лейкози та членів їх родин є одним 3 найважливіших напрямків у діяльності громадських та благодійних організацій, що функціонують в онкології за кордоном та в Україні. Важливою перешкодою в організації роботи вітчизняних благодійних організацій $\epsilon$ відсутність відповідної нормативно-правової бази та продуктивного досвіду в організації ефективної роботи. Важливе значення лікарі приділяють також питанню реформування онкогематологічної служби в Україні (IV позиція у рейтингу) та підвищенню заробітної плати медичним працівникам (V позиція).

Приблизно кожен другий опитаний лікар (58,70 \% - 52,17 \% від загальної кількості опитаних) вважає за необхідне «впровадження ДЦП «Гематологія»», «збільшення доходів населення» та «посилення ролі

Таблиця 1. Рейтинг фракторів щодо призначень ЛП у хворих на лейкози

\begin{tabular}{|c|c|c|c|}
\hline Фактори & $\begin{array}{l}\text { Кіль-ть } \\
\text { опит. }\end{array}$ & $\%$ & $\begin{array}{l}\text { Рейтинг } \\
\text { фрактора }\end{array}$ \\
\hline Клінічна стадія розвитку патологічного процесу & 92 & 100,00 & I \\
\hline Загальний стан хворого & 92 & 100,00 & I \\
\hline $\begin{array}{l}\text { Наявність лікарського препарату (ЛП) у протоколах надання } \\
\text { медичної допомоги за спеціальністю «Гематологія» та Державному } \\
\text { формулярі (ДФ) лікарських засобів (ЛЗ) }\end{array}$ & 86 & 93,48 & II \\
\hline $\begin{array}{l}\text { Наявність доказової бази за параметрами ефективність/безпечність/ } \\
\text { раціональність }\end{array}$ & 74 & 80,04 & III \\
\hline $\begin{array}{l}\text { Власний клінічний досвід ефективності застосування ЛП у лікуванні } \\
\text { хворих }\end{array}$ & 67 & 72,83 & IV \\
\hline Низький рівень розвитку побічної дії ЛП у пацієнтів & 51 & 55,44 & $\mathrm{~V}$ \\
\hline Низька ціна препарату & 34 & 36,96 & $\mathrm{VI}$ \\
\hline $\begin{array}{l}\text { Інформація про наявність ЛП в аптечній мережі, що обслуговує за- } \\
\text { клад охорони здоров'я (3О3) }\end{array}$ & 27 & 29,35 & VII \\
\hline $\begin{array}{l}\text { Вираженість симптоматичних проявів захворювання на фроні прийо- } \\
\text { му препаратів }\end{array}$ & 25 & 27,17 & VIII \\
\hline Інші причини & 18 & 19,57 & IX \\
\hline Традиційність застосування & 15 & 16,30 & $\mathrm{X}$ \\
\hline $\begin{array}{l}\text { Застосування саме цього найменування у зв'язку з відсутністю більш } \\
\text { ефективного лП }\end{array}$ & 10 & 10,87 & $\mathrm{XI}$ \\
\hline
\end{tabular}

ISSN 2312-0967. Фармацевтичний часопис. 2015. № 2 
Таблиця 2. Основні напрямки вирішення проблеми підвищення рівня організації та фрінансування лікувальнодіагностичного процесу й фрармацевтичного забезпечення хворих на лейкози (думка експертів)

\begin{tabular}{|c|c|c|c|}
\hline Напрямки вирішення проблеми & $\begin{array}{l}\text { Кіль-ть } \\
\text { опит. }\end{array}$ & $\%$ & $\begin{array}{l}\text { Рейтинг } \\
\text { фрактора }\end{array}$ \\
\hline $\begin{array}{l}\text { Реформування вітчизняної системи охорони здоров'я у напрямку } \\
\text { впровадження моделі обов'язкового медичного страхування (ОМС) }\end{array}$ & 92 & 100,00 & I \\
\hline Матеріально-технічне переобладнання 303 & 84 & 91,30 & II \\
\hline $\begin{array}{l}\text { Активізація та координація діяльності громадських та благодійних } \\
\text { фрондів }\end{array}$ & 83 & 90,22 & III \\
\hline Рефрормування онкогематологічної служби України & 77 & 83,70 & IV \\
\hline Підвищення заробітної плати медичним працівникам & 68 & 73,91 & $\mathrm{~V}$ \\
\hline Впровадження державної цільової програми (ДЦП) «Гематологія»» & 54 & 58,70 & $\mathrm{VI}$ \\
\hline Збільшення доходів населення & 51 & 55,44 & VII \\
\hline $\begin{array}{l}\text { Збільшення обсягів державного фрінансування зі збереженням } \\
\text { існуючої бюджетної моделі фрінансування медицини }\end{array}$ & 50 & 54,35 & VIII \\
\hline $\begin{array}{l}\text { Посилення ролі державних органів у процесі контролю за розподілом } \\
\text { та есективністю використання бюджетних коштів }\end{array}$ & 48 & 52,17 & IX \\
\hline Підвищення вимог до кваліфрікаційного рівня лікарів та фрармацевтів & 12 & 13,04 & $\mathrm{X}$ \\
\hline Розвиток сімейної медицини у практичній охороні здоров'я & 7 & 7,61 & $\mathrm{XI}$ \\
\hline
\end{tabular}

державних органів у процесі контролю за розподілом та ефрективністю використання бюджетних коштів». Цікавим є той фракт, що при наявності стовідсоткової підтримки опитаними лікарями напрямку запровадження соціальної моделі ОМС, половина 3 них же (50 опитаних - 54,35 \%) вважає за необхідне збільшення обсягів державного фрінансування зі збереженням існуючої бюджетної моделі фрінансування медицини. Встановлене протиріччя в оцінці експертами напрямків вирішення проблеми, яка розглядається, пов'язане, на нашу думку, з інертністю мислення або недостатнім рівнем обізнаності лікарів за комплексом проблем щодо впровадження ОМС у вітчизняну СО3.

На наступне закрите запитання «як можна оцінити рівень забезпечення потреби в ЛП у 303, де Ви працюєте?» практично кожен другий опита- ний (43,49 \%) відмітив варіант відповіді «менш ніж 25 \% від потреби у лП» (рис. 1). Жоден лікар не відмітив відповідь «0\% від необхідної потреби у лП» та «100 \% задоволення потреби в ЛП».

На запитання «Як часто у Вас виникає необхідність призначення дорогих імпортних ліків, що не входять до переліку ЛЗ і ВМП, які закуповуються за бюджетні кошти у 303?» практично однакова за кількістю сукупність опитаних експертів вказала варіанти відповідей «Часто» (38 лікарів - 41,30 \%) та «Зрідка» (36 - 39,13 \%), а решта обрала відповідь «Дуже часто» (18 - 19,57 \%). При цьому жоден опитаний лікар не відмітив варіант відповіді «Не виникає ніколи». Враховуючи вкрай низьку платоспроможність населення України, логічним виглядає результат відповіді лікарів на наступне запитання «як часто пацієнти відмовляються від

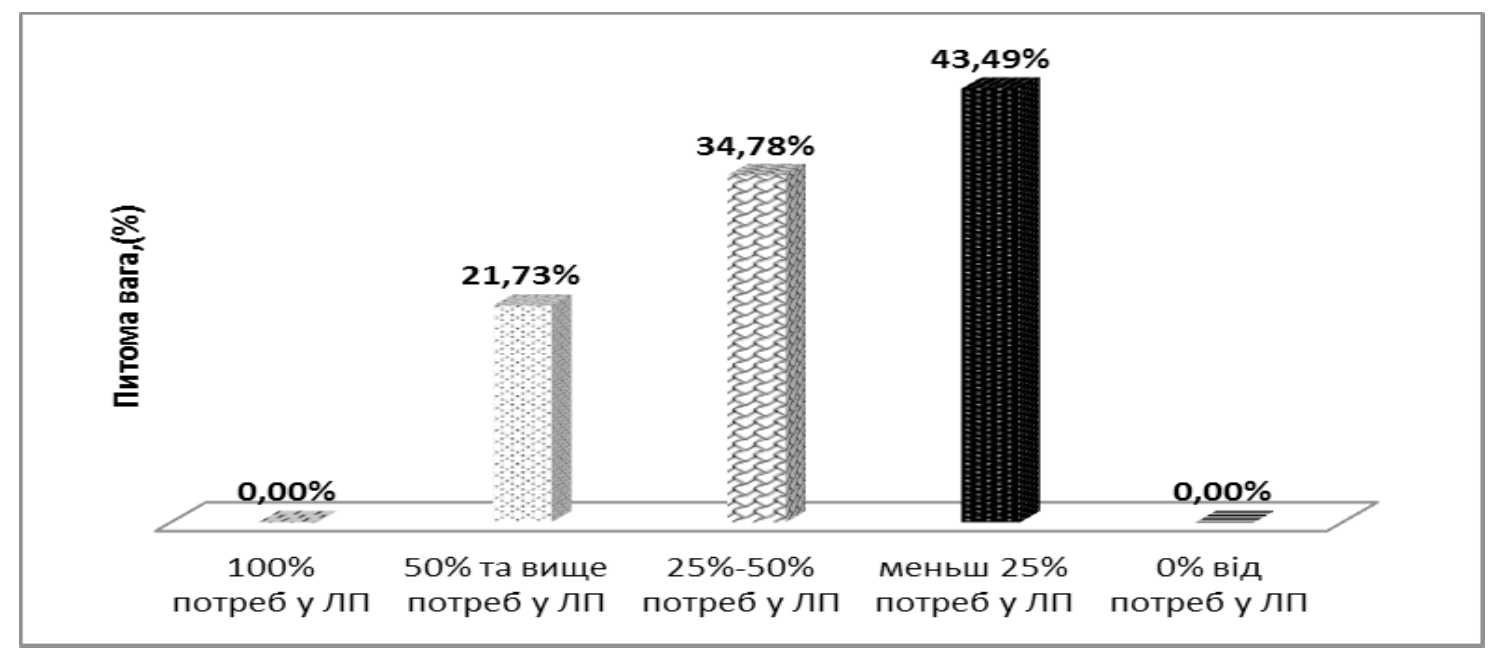

Рис. 1. Експертна оцінка рівня задоволення потреби в лп у 303.

ISSN 2312-0967. Pharmaceutical review. 2015. № 2 
прийому Л3, що пропонуються у 303, віддаючи перевагу самостійній купівлі імпортних препаратіваналогів?». Три четвертих опитаних лікарів (70 експертів - 76,09 \%) відповіли «Дуже рідко», а 18 (19,57\%) опитаних відмітили відповідь «Практично ніколи». Лише 4 експерти (4,35 \%) відмітили відповідь «У 50 \% випадків». Жоден лікар не зазначив варіант відповіді «У більшості випадків». Як бачимо, проблеми фрінансового забезпечення в організації лікувальнодіагностичного процесу та фрармацевтичного забезпечення хворих на лейкози займають пріоритетне місце та потребують негайного вирішення, що повною мірою можливе лише за умов впровадження соціальної моделі ОМС.

Далі лікарям пропонували відповісти на таке запитання «Чи вважаєте Ви за доцільне при бюджетних закупівлях лз віддавати перевагу вітчизняним препаратам-аналогам?». За результатами обробки анкет встановлено, що більше половини опитаних 55 $(59,78 \%)$ відмітили негативний варіант відповіді. 28 експертів (30,44 \%) опитаних лікарів мали труднощі з відповіддю, а всього 9 експертів (9,78 \%) відповіли позитивно. Значна більшість експертів за умов дефіциту коштів у СОЗ вважають закупівлю імпортних ЛЗ, що застосовуються у хіміотерапії (XT), більш доцільною. Це зумовлено, на нашу думку, більш високими клініко-економічними параметрами ефективності застосування імпортних ЛП порівняно з вітчизняними препаратами-аналогами. Як свідчать результати маркетингового аналізу сегменту ринку протипухлинних препаратів (ПП), більшість найменувань імпортних препаратів, що представлені в Україні, є оригінальними ЛП [7]. Безумовним $€$ той фракт, що оригінальні ЛП апріорі мають більш високі клініко-економічні характеристики, ніж їх препарати-генерики (копії).

Наступний блок запитань мав на меті визначити основні проблеми в організації ефективного забезпечення лікарів інфрормацією про ЛП. Питання інформаційного забезпечення лікувально-діагностичного процесу в практичній онкології та гематології набувають особливого значення за умов активного розвитку ринку ПП, що спостерігається у світі та в Україні. На запитання «Чи маєте Ви достатню інформацію стосовно нових препаратів і схем XT хворих на лейкози?» більше половини 54 (58,69 \%) опитаних лікарів відповіли позитивно. Про частковий характер задоволення інорормаційних потреб було зазначено у 24 анкетах (26,09 \%), 13 експертів (14,13 \%) мали труднощі з відповіддю і лише один експерт відмітив відповідь «Не маю достатньо». Наступне питання передбачало на меті визначити оптимальні форми надання інформації про нові ЛЗ та схеми ХТ хворих на лейкози. Найбільшу кількість відповідей набрали такі форми надання інформації, як «аналітичні та стислі огляди» та «анотації на монографії, журнальні статті тощо». Зазначені варіанти відповідей відмітили по 70 (76,09 \%) лікарів відповідно. Далі з істотним відривом були представ- лені такі варіанти відповідей, як «автоматизовані інорормаційно-пошукові системи» - 42 (45,65 \%) експерти. «Тематичні огляди» вважають ефрективними 30 (32,61 \%) експертів, а «експрес-інорормацію або сигнальніповідомлення»-23(25,00\%) лікаря. Варіантвідповіді «теле- та радіореклама» був зазначений всього 7 (7,61 \%) експертами. Цей фракт $€$ логічним, враховуючи особливість надання орармацевтичної та медичної допомоги хворим на лейкози. Так, за даними клініко-економічного аналізу (КЕА) лікарських призначень хворим на лейкози, що проводився нами раніше, встановлено значне домінування (до 90 \%) рецептурних Л3, реклама яких у відкритому інорормаційному просторі заборонена. Тому зрозумілою $€$ спрямованість опитаних лікарів на фрахову за змістом та фрормою подання інформацію. Представників фрармацевтичних компаній повинен зацікавити той фракт, що жоден з опитаних лікарів не відмітив варіант відповіді «Рекламні листи та інорормаційні буклети, що пропонуються представниками фрірм-виробників ЛП».

Наприкінці анкети були представлені питання, відповіді на які дали змогу оцінити рівень фрармацевтичного забезпечення хворих на лейкози. Враховуючи реалії існуючої системи фрармацевтичного забезпечення в Україні, логічним виглядає результат опитування лікарів на запитання «У 303, де Ви працюєте, є міжлікарняна аптека державної (комунальної) власності, що обслуговує стаціонарних хворих?». Більш ніж три четвертих опитаних (71 лікар - 77,17 \%) відповіли негативно. Мали труднощі з відповіддю 8 опитаних (8,70 \%), а решта відповіли позитивно (13 експертів - 14,13\%). У разі негативної відповіді експертам було запропоновано визначити доцільність впровадження діяльності зазначеної аптеки. Більшість експертів, які відповіли негативно на попереднє запитання (56 лікарів - 78,87 \% від 71 опитаних), вважають за необхідне організацію роботи у 303 міжлікарняної аптеки, яка б спеціалізувалася на обслуговуванні стаціонарних хворих. Два експерти (2,82 \%) відмітили варіант відповіді «Ні, не потрібно», а 13 (18,31\%) опитаних мали труднощі 3 відповіддю. Далі експертам було запропоновано визначити рівень співпраці аптечних закладів та 303, у яких вони безпосередньо працюють у напрямку організації ефективного лікування хворих на лейкози. Результати опитування наведені на рисунку 2.

Як бачимо, більшість опитаних (52 лікаря) оцінюють рівень зазначеної співпраці як «задовільний». Кожен третій опитаний (30 експертів) відмітили варіант відповіді «низький» і лише 10 лікарів вважають, що ефективність співпраці аптечних закладів та 303, де вони працюють, висока. Позитивним є той фракт, що жоден експерт, відповідаючи на зазначене питання, не відмітив варіант відповіді «незадовільний».

Важливим етапом досліджень, на нашу думку, стало визначення фракторів, які впливають на рівень

ISSN 2312-0967. Фармацевтичний часопис. 2015. № 2 


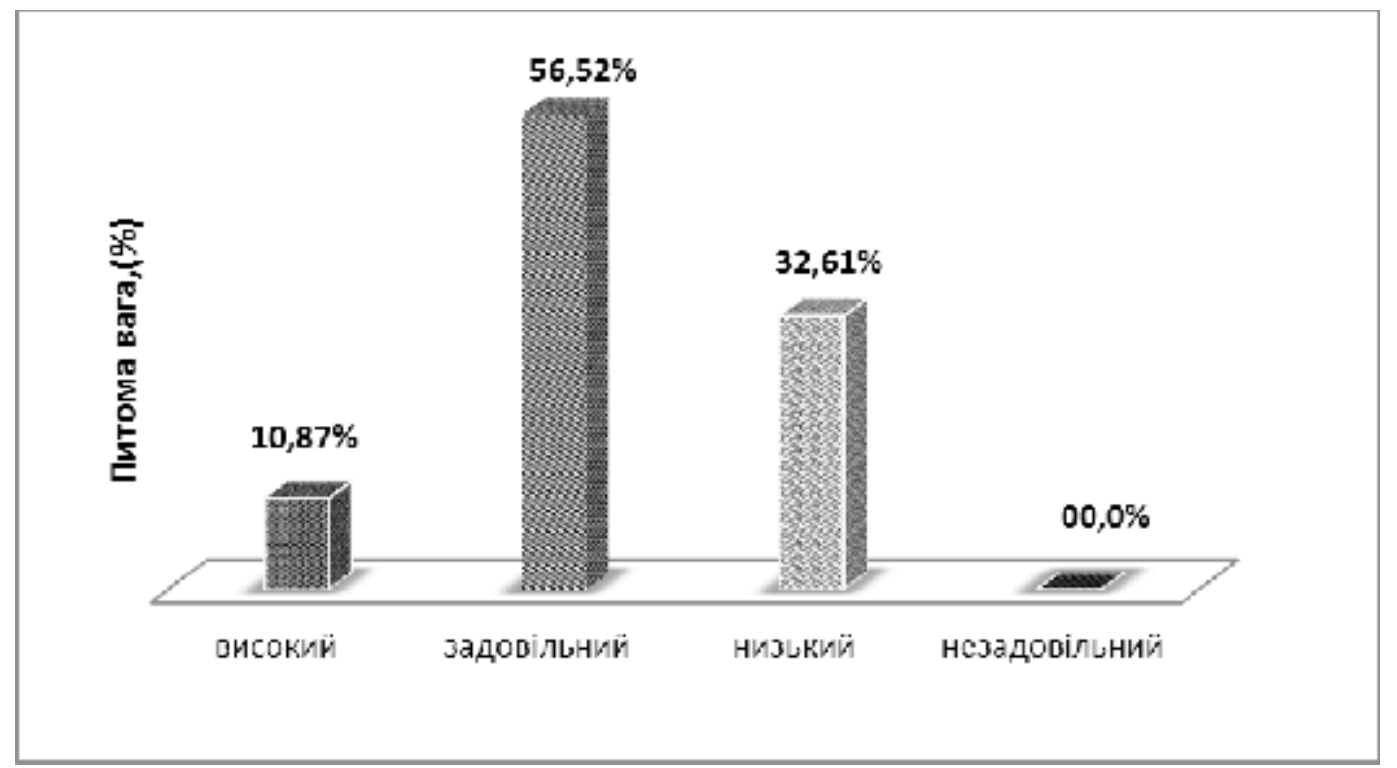

Рис. 2. Оцінка експертів рівня співпраці аптечних закладів та 303 в організації лікувального процесу хворих на лейкози.

співпраці аптечних закладів та 303, а також проблем у фрармацевтичному забезпеченні хворих на лейкози в Україні (табл. 3). До основних (I-III позиції у рейтингу) експертами були віднесені фрактори

Таблиця 3. Рейтинг фракторів, що впливають на рівень співпраці аптечних закладів та 303 та основних проблем у фрармацевтичному забезпеченні хворих на лейкози в Україні

\begin{tabular}{|c|c|c|c|}
\hline Фактори/Проблеми & $\begin{array}{l}\text { Кіль-ть } \\
\text { опит. }\end{array}$ & $\%$ & $\begin{array}{l}\text { Рейтинг } \\
\text { фрактора }\end{array}$ \\
\hline \multicolumn{4}{|c|}{ Фактори, що впливають на рівень співпраці аптечних закладів та 303} \\
\hline Цінова доступність лП & 71 & 77,17 & I \\
\hline Кваліфікаційний рівень лікарів та провізорів/срармацевтів & 67 & 72,83 & II \\
\hline Широта асортименту ЛП, що пропонується в аптеці & 66 & 71,74 & III \\
\hline Територіальна близькість аптечних закладів & 61 & 66,30 & IV \\
\hline Особисті якості та налагоджені контакти керівників закладів & 39 & 42,39 & $\mathrm{~V}$ \\
\hline Рівень інфрормаційної роботи аптечного закладу & 32 & 34,78 & VI \\
\hline Традиційний характер стосунків, що напрацьований роками співпраці & 5 & 5,43 & VII \\
\hline Форма власності аптеки & 4 & 4,35 & VIII \\
\hline \multicolumn{4}{|c|}{ Проблеми у фрармацевтичному забезпеченні хворих на лейкози в Україні } \\
\hline Низькі доходи населення & 87 & 94,57 & 1 \\
\hline $\begin{array}{l}\text { Недостатній рівень бюджетного фрінансування цільової програми } \\
\text { «Онкологія» }\end{array}$ & 68 & 73,91 & II \\
\hline $\begin{array}{l}\text { Відсутність системної та чіткої державної політики у фрармацевтично- } \\
\text { му секторі економіки }\end{array}$ & 57 & 61,97 & III \\
\hline Домінування бізнесових інтересів аптеки над її соціальною фрункцією & 54 & 58,70 & IV \\
\hline Хаотичний характер розвитку вітчизняного фрармацевтичного ринку & 52 & 56,52 & $\mathrm{~V}$ \\
\hline Високий рівень корупції у фрармацевтичному бізнесі & 50 & 54,35 & $\mathrm{VI}$ \\
\hline $\begin{array}{l}\text { Відсутність дієвих механізмів компенсації (реімбурсації) вартості } \\
\text { спожитих ліків }\end{array}$ & 47 & 51,09 & VII \\
\hline Недостатній рівень кваліфрікації провізорів/срармацевтів & 21 & 22,83 & VIII \\
\hline Нецільове використання бюджетних коштів & 18 & 19,57 & IX \\
\hline $\begin{array}{l}\text { Відсутність фрінансової зацікавленості аптек у співпраці з 3О3, що } \\
\text { обслуговують хворих на лейкози }\end{array}$ & 12 & 13,04 & $\mathrm{X}$ \\
\hline
\end{tabular}

ISSN 2312-0967. Pharmaceutical review. 2015. № 2 
«цінової доступності лП», «кваліфрікаційного рівня лікарів та провізорів/орармацевтів» та наявності «широкого асортименту препаратів у аптеках». Важливе значення в організації зазначеної співпраці, на думку опитаних лікарів, має наявність територіальної близькості аптек та 303 один від одного (IV позиція у рейтингу). Далі, з істотним відривом (39 опитаних 42,39\%), представлений фрактор «особисті якості та налагоджені контакти керівників закладів».

Практично кожен третій експерт вважає важливим фрактором «рівень інформаційної роботи аптечного закладу». Найменшу кількості відповідей (4 експерти - 4,35 \%) отримав варіант «фрорма власності аптеки», що є цікавим, враховуючи той фракт, що 56 опитаних лікарів вважають за необхідне організацію роботи міжлікарняної аптеки саме державної (комунальної) форми власності, яка б спеціалізувалась на обслуговуванні стаціонарних хворих.

Домінуючими проблемами в організації ефрективного фрармацевтичного забезпечення хворих на лейкози більшість експертів вважає фрінансові, а саме «низькі доходи населення» та «недостатній рівень бюджетно- го фрінансування цільової програми «Онкологія» (I та II позиції у рейтингу відповідно), що є логічним, враховуючи реалії сьогодення за умов функціонування бюджетної моделі медицини в країні. Замикає трійкулідерів варіант відповіді «відсутність системної та чіткої державної політики у фрармацевтичному секторі економіки» $(61,97 \%)$. Кожен другий опитаний лікар вважає важливим вплив на ефективність зазначеного процесу внутрішніх фракторів розвитку вітчизняної системи фармацевтичного забезпечення населення. Варіанти відповідей «домінування бізнесових інтересів аптеки над її соціальною фрункцією» (58,70 \%), «хаотичний характер розвитку вітчизняного фрармацевтичного ринку» (56,52 \%), «високий рівень корупції у фрармацевтичному бізнесі» $(54,35 \%)$ у рейтингу оракторів були представлені один за одним. Окрім цього, половина опитаних (51,09 \%) оцінили важливість такого фрактора, як «відсутність дієвих механізмів компенсації (реімбурсації) вартості спожитих ліків». Незначним чином впливають на фрармацевтичне забезпечення хворих на лейкози, на думку лікарів, такі фрактори: «недостатній рівень кваліфрікації провізорів/

Таблиця 4. Заходи з підвищення ефективності фармацевтичного забезпечення хворих на лейкози в Україні

\begin{tabular}{|c|}
\hline Перелік заходів за рівнями їх реалізації в Україні \\
\hline Макроекономічний рівень: \\
\hline $\begin{array}{l}\text { впровадження соціальної моделі ОМС; } \\
\text { перегляд складу діючого Національного переліку основних лз і ВМП на відповідність вимогам сучасної } \\
\text { онкогематології (наприклад, внесення змін за такими найменуваннями, як іматиніб, дазатиніб та нілотиніб); } \\
\text { державна підтримка вітчизняного виробника Пп за допомогою механізмів кредитування, оподаткування, } \\
\text { ціноутворення та інвестування; } \\
\text { розробка та ефективне впровадження антикризової програми у сфері організації тендерних торгів з закупівель } \\
\text { лз за дцП; } \\
\text { державна підтримка аптечних закладів різних фрорм власності та господарювання, що спеціалізуються на } \\
\text { обслуговуванні онкогематологічних хворих, в т. ч. на лейкози; } \\
\text { налагодження плідної співпраці з міжнародними організаціями, що займаються питаннями допомоги хворим на } \\
\text { онкогематологічні патології, в т. ч. на лейкоз; } \\
\text { розробка та впровадження дієвих механізмів компенсації вартості спожитих лп для різних верств населення } \\
\text { та груп хворих; } \\
\text { підвищення рівня профілактики та первинної діагностики онкогематологічних захворювань, особливо у } \\
\text { регіонах з високими показниками захворюваності, смертності та поширеності гемобластозів, в т. ч. лейкозів; } \\
\text { розробка та впровадження дцп «Гематологія», яка вже проходила процедуру експертної оцінки та громадсь- } \\
\text { кого обговорення у 2010 р.; } \\
\text { підвищення рівня оплати праці лікарів-онкологів та лікарів-гематологів; } \\
\text { створення з боку держави сприятливих умов щодо ефективної співпраці громадських, благодійних та інших } \\
\text { організацій, з одного боку, та з ЗОз й виробників Пп, з іншого; } \\
\text { підвищення рівня післядипломної підготовки лікарів-онкологів та лікарів-гематологів. }\end{array}$ \\
\hline $\begin{array}{c}\text { Рівень спеціалізованих 303, у яких надають медичну допомоги та здійснюється фрармацевтичне забезпечення } \\
\text { хворих на лейкози (мікроекономічний): }\end{array}$ \\
\hline $\begin{array}{l}\text { впровадження постійно діючих формулярних комітетів у складі 3ОЗ, метою фрункціонування яких } є \text { КЕА } \\
\text { раціональності використання ресурсів, що виділяються з державного бюджету та страхових компаній з ОМс; } \\
\text { активізація співпраці клінічних провізорів з лікарями за комплексом питань, що стосуються впровадження раціо- } \\
\text { нальних моделей фрармацевтичного забезпечення хворих за умов обмеженого характеру фінансування 3ОЗ; } \\
\text { впровадження автоматизованих пошуково-інформаційних систем в організацію надання медичної допомоги та } \\
\text { фрармацевтичного забезпечення хворих на лейкози, насамперед з метою постійного моніторингу вітчизняного } \\
\text { ринку ПП, структури лікарських призначень та споживання л3; } \\
\text { підвищення ефективності співпраці лікарів з провізорами/срармацевтами, що здійснюють фрармацевтичне за- } \\
\text { безпечення хворих на лейкози }\end{array}$ \\
\hline
\end{tabular}

ISSN 2312-0967. Фармацевтичний часопис. 2015. № 2 
фрармацевтів» (22,83%); «нецільове використання бюджетних коштів» (19,57 \%); «відсутність фрінансової зацікавленості аптек у співпраці 3 303, що обслуговують хворих на лейкози» (13,04 \%). За результатами проведеного анкетування лікарів та систематизації даних досліджень, проведених нами раніше, а також враховуючи українські наміри щодо вступу країни до ЄС та рефрормування вітчизняної СО3 у напрямку впровадження ОМС, нами запропоновані заходи з підвищення ефективності фрармацевтичного забезпечення хворих на лейкози на двох рівнях, а саме макроекономічному (перший рівень реалізації заходів) та рівні 303 (другий рівень) (табл. 4) [3, 5-7].

Висновки. 1. За результатами обробки даних анкетування встановлено, що у рейтингу важливості фракторів, які впливають на призначення лП, лідируючі позиції зайняли фактори клініко-економічного та нормативного-правового характеру. Найменш важливими, на думку експертів, $€$ ті, що пов'язані з традиційністю призначень та можливістю застосування того або іншого найменування лП за відсутністю більш ефективного препарату.

2. Доведено, що більшість експертів лише частково задоволена рівнем організації та фрінансування медичної допомоги та фармацевтичного забезпечення хворих на лейкози, а основним напрямком вирішення зазначеної проблеми 100 \% опитаних вважають впровадження ОМС в Україні.

3. Практично кожен другий експерт зазначив про низький рівень задоволення потреби в ЛП (варіант відповіді «менш ніж 25 \% від потреби у лП»), а більше половини опитаних вважає за недоцільне віддавати перевагу вітчизняним препаратам-аналогам при бюджетних закупівлях ЛЗ.

4. Встановлене суперечливе ставлення експертів в оцінці частоти призначень ЛП, які закуповуються за бюджетні кошти. Практично аналогічна кількість опитаних відмітили варіант відповіді «часто призначаються» та «рідко призначаються». При цьому 75 \% експертів зазначили, що пацієнти «дуже рідко» відмовляються від приймання наявних у 303 лП, віддаючи перевагу самостійній оплаті імпортних препаратів-аналогів.

5. Більше половини лікарів вважає, що мають достатню інформації про нові ЛП та схеми ХT, а найбільш доцільними у роботі вважають такі фрорми їі отримання, як «аналітичні та стислі огляди» та «анотації на монографії, журнальні статті тощо».

6. Понад 77,1 \% опитаних зазначили в аптеках про відсутність міжлікарняної аптеки державної (комунальної) фрорми власності, яка обслуговувала стаціонарних хворих у 303, де вони працюють, а 56 експертів вважають за доцільне організацію роботи зазначеної аптеки.

7. Більше половини опитаних лікарів оцінили рівень співпраці аптечних закладів та 303, де вони працюють як «задовільний», а основним фрактором, який впливає на її рівень, вважають «цінову доступності ЛП».

8. До основних проблем в організації фрармацевтичного забезпечення хворих на лейкози експерти віднесли фрінансові за змістом фрактори, а саме «низькі доходи населення» та «недостатній рівень бюджетного фрінансування цільової програми «Онкологія». Важливе значення, на думку експертів, має проблема «відсутності системної та чіткої державної політики у фрармацевтичному секторі економіки».

9. Систематизація отриманих результатів та даних раніше проведених досліджень дозволила розробити перелік заходів щодо підвищення ефективності фрармацевтичного забезпечення хворих на лейкози в Україні, які повинні реалізовуватися на двох рівнях (макроекономічному та рівні 303). Розробка ефективних механізмів їх реалізації й формує спектр перспективних досліджень у зазначеному напрямку.

\section{Література}

1. Видиборець С. В. Сучасні досягнення в діагностиці та лікуванні гострих лейкозів / С. В. Видиборець // Здоров'я України. - 2008. - № 17/1. - С. 60-62.

2. Мендрік О. А. Фармакоекономічні дослідження лікарських засобів, які використовуються в онкогематології : автореср. дис. на здобуття наук. ступеня канд. фрармац. наук : [спец.] 15.00.01 "Технологія ліків, організація фрармацевтичної справи та судова фрармація" / Мендрік Олена Анатоліївна; Львів. нац. мед. ун-т ім. Данила Галицького. - Львів, 2013. - 24 с.

3. Немченко А. С. Дослідження стану організації фрармацевтичної допомоги хворим за державними цільовими програмами «Туберкульоз», «СНІД», «Онкологія» та «Дитяча онкологія» / А. С. Немченко, Г. Л. Панфрілова, Ю. В. Корж // Управління, економіка та забезпечення якості в фрармації. - 2009. - № 3(5). - С. 65-71.

4. Новак Л. В. Онкогематологія в Україні: проблеми діагностики та лікування / Л. В. Новак, 3. В. Масляк, В. Л. Матлан // Онкологія. - 2006. - Т. 8, № 2. - С. 163 - 170.

5. Панорілова Г. Л. Аналіз нормативно-правових та фрармакотерапевтичних підходів у срормуванні державних закупівель лікарських засобів для хворих на гемобластози в Україні / Г. Л. Панфілова, О. В. Цурікова // Фармаком. - 2014. - № 2. - С. 14 - 19.

6. Панфрілова Г. Л. Клініко-економічний аналіз стану лікарського забезпечення хворих на лейкоз в Україні : методичні рекомендації / Г. Л. Панфілова, О. В. Цурікова. - К. : Український центр наукової медичної інфрормації та патентно-ліцензійної роботи, 2014. - 25 с.

7. Панфрілова Г. Л. Обґрунтування заходів з підвищення ефективності фрармацевтичного забезпечення хворих на лейкози в Україні : методичні рекомендації/Г. Л. Панорілова, О. В. Цурікова. - К. : Український центр наукової медичної інформації та патентно-ліцензійної роботи, 2014. - 33 с.

8. РеброваО. Ю. Статистический анализмедицинскихданных. Применение пакета прикладных программ STATISTICA / О. Ю. Реброва. - М. : Медиассрера, 2003. - С. 208-216.

ISSN 2312-0967. Pharmaceutical review. 2015. № 2 


\title{
АНАЛИЗ ПРОБЛЕМ И РАЗРАБОТКА МЕРОПРИЯТИЙ ПО ПОВЫШЕНИЮ ЭФФЕКТИВНОСТИ ФАРМАЦЕВТИЧЕСКОГО ОБЕСПЕЧЕНИЯ БОЛЬНЫХ ЛЕЙКОЗАМИ В УКРАИНЕ
}

\author{
А. Л. Панфрилова, О. В. Цурикова \\ Национальный фрармацевтический университет, Харьков
}

Резюме: в статье представлены результаты анкетирования врачей онкологов и гематологов по комплексу вопросов, касающихся организации оказания медицинской и фармацевтической помощи больным лейкозами в Украине. Единогласно по оценке врачей решения проблем в организации эффективной медицинской и фрармацевтической помощи должны реализоваться в плоскости введения обязательно медицинского страхования в практическое здравоохранение. Почти каждый второй эксперт указал на низкий уровень удовлетворения потребности в лекарственных препаратах (вариант ответа «менее чем 25 \% от потребности в лекарствах»), а более половины опрошенных считают нецелесообразным отдавать предпочтение отечественным препаратам-аналогам при бюджетных закупках лекарств. К основным проблемам в организации фрармацевтического обеспечения больных лейкозами экспертами отнесены финансовые по содержанию («низкие доходы населения» и «недостаточный уровень бюджетного фринансирования целевой программы «Онкология»), важное значение имеет также «отсутствие системной и четкой государственной политики в фрармацевтическом секторе экономики». По результатам проведенных исследований разработан перечень мероприятий по повышению эфффективности фрармацевтического обеспечения больных лейкозами в Украине, которые должны реализоваться на двух уровнях (макроэкономическом и уровне учреждений здравоохранения).

Ключевые слова: экспертный опрос, лейкоз, фрармацевтическая помощь, фрармацевтическое обеспечение.

\section{ANALYSIS OF PROBLEMS AND DEVELOPING MEASURES TO IMPROVE THE EFFECTIVENESS OF THE PHARMACEUTICAL PROVIDING OF PATIENTS WITH LEUKOSIS IN UKRAINE}

\author{
H. L. Panfilova, O. V. Tsurikova \\ National University of Pharmacy, Kharkiv
}

Summary: the article presents the results of the survey of doctors of oncology and hematology at a range of issues relating to the organization of medical and pharmaceutical care to patients with leukosis in Ukraine. Evaluation of all the doctors who participated in the survey, problem-solving in the organization of effective medical and pharmaceutical care must be realized in the plane the introduction of compulsory health insurance in the healthcare practice. Almost every second expert pointed out about the low level of satisfaction of needs in drug discovery (the answer is "less than $25 \%$ of the need for drugs"). More than half of the respondents consider it inappropriate to give preference to domestic drugs peers in the implementation of the budget procurement of medicines. The main problems in the organization of pharmaceutical providing of leukosis patients, doctors attributed the financial ("low incomes" and "insufficient budget financing program "Oncology"). Experts also believe that the importance of a "lack of systematic and clear governmental policy in the pharmaceutical sector of the economy". The results of the research, a list of measures to improve the efficiency of pharmaceutical providing of leukosis patients in Ukraine. These measures should be implemented at two levels (macro-economic and health facility level).

Key words: expert survey, leukosis, pharmaceutical care, pharmaceutical providing. 